\title{
Increased Levels of Hyaluronic Acid in Bronchoalveolar Lavage from Patients with Interstitial Lung Diseases, Relationship with Lung Function and Inflammatory Cells Recruitment
}

\author{
Glenda Ernst ${ }^{*}$, Jancic Carolina ${ }^{2}$, Auteri Santiago1, Rodriguez Moncalvo Juan1, \\ Galíndez Fernando1, Grynblat Pedro' ${ }^{1}$ E. Hajos Silvia ${ }^{3}$ \\ ${ }^{1}$ Respiratory Rehabilitation Hospital María Ferrer, Buenos Aires, Argentina \\ ${ }^{2}$ National Academy of Medicine, IMEX-CONICET, Buenos Aires, Argentina \\ ${ }^{3}$ Faculty of Pharmacy and Biochemistry, Immunology, IDEHU, UBA-CONICET, Buenos Aires, Argentina \\ Email: "glenda.uba@gmail.com
}

Received 6 February 2014; revised 5 March 2014; accepted 12 March 2014

Copyright (C) 2014 by authors and Scientific Research Publishing Inc.

This work is licensed under the Creative Commons Attribution International License (CC BY).

http://creativecommons.org/licenses/by/4.0/

(c) () Open Access

\begin{abstract}
Purpose: Interstitial Lung Diseases (ILD) are characterized by inflammation and fibrosis. It described the role of hyaluronic acid (HA) as an immune-regulator. It is not known if $\mathrm{HA}$ contributes to the recruitment of inflammatory cells associated with ILD. If this hypothesis was correct, then concentrations of HA in bronchoalveolar lavage (BAL) should correlate with the severity of ILD. Methods: We collected BAL from 22 ILD patients and 15 control subjects. We determined HA and cytokine levels by ELISA. In vitro chemotaxis assays were performed by using a transwell system. Results: We found that ILD patients showed a significant increase in HA, IL-6 levels and the amount of cells in BAL compared to control subjects. We detected a significant positive correlation between HA and IL- 6 levels ( $r=0.53$ and $p<0.001)$ and an inverse relationship between $H A$ levels and diffusion capacity $(\mathrm{r}=-0.59, \mathrm{p}<0.01)$. In vitro, HA induced migration of macrophages and monocytes through a CD44-dependent process. BAL from patients with ILD stimulated macrophage migration and this was abrogated by hyaluronidase. Conclusions: Our results support the hypothesis that HA contributes to the recruitment of monocytes towards the alveolar space, leading to exacerbation of lung inflammation in ILD patients.
\end{abstract}

\footnotetext{
"Corresponding author.
}

How to cite this paper: Ernst, G., et al. (2014) Increased Levels of Hyaluronic Acid in Bronchoalveolar Lavage from Patients with Interstitial Lung Diseases, Relationship with Lung Function and Inflammatory Cells Recruitment. Modern Research in Inflammation, 3, 27-36. http://dx.doi.org/10.4236/mri.2014.32004 


\section{Keywords}

\section{Hyaluronic Acid, Interstitial Lung Diseases, Lung Inflammation}

\section{Introduction}

Interstitial lung diseases (ILD) include a heterogeneous group of lung disorders that lead to progressive loss of lung function [1]. These illnesses share in common parenchymal inflammation and fibrosis with overproduction and deposition of extracellular matrix (ECM) components, distortion of pulmonary architecture, and intra-alveolar inflammation [2]-[6].

Hyaluronic acid (HA) is a non-sulfated glycosaminoglycan (GAG) composed by disaccharide D-glucuronic acid and $\mathrm{N}$-acetyl-glucosamine. It represents the major component of the ECM and it has been described as an immune regulator in human diseases [7]. It has been previously demonstrated that HA levels are significantly higher in bronchoalveolar lavage (BAL) from patients with respiratory distress syndrome [8], idiopathic pulmonary fibrosis [9] and sarcoidosis [10] compared with healthy people.

HA interacts with different cell surface receptors such as CD44 and Toll-like receptor 2 and 4 (TLR-2 and TLR-4) [11] [12]. The interaction of HA with CD44 induces cell motility. Activation of CD44 can also modulate proliferation, migration and angiogenesis [13]. Moreover, HA isolated from serum of patients with acute lung injury stimulates the production of chemokines by macrophages in TLR-4 and TLR-2 dependent manner [14].

The innate immune system plays a pivotal role in the initiation and progression of lung inflammation. HA has been described as a "Damage-Associated Molecular Pattern" (DAMPs), with potential to contribute with sterile inflammation associated with ILD pathogenic process [15], however, the role of HA in the inflammatory cell recruitment in these patients, remains unclear. In the present study we analyzed HA levels in BAL fluid from different ILD and we evaluated the ability of HA to induce the chemotaxis of alveolar macrophages and circulating monocytes.

\section{Materials and Methods}

\subsection{Study Design}

The study had a prospective cross-sectional design. The protocol was approved by the ethical committee of Hospital "María Ferrer" in according with the ethical standards of Helsinski Declaration (1975). Informed consent was obtained from all patients and control subjects.

\subsection{Patients and Controls}

\subsubsection{Patients with Interstitial Lung Diseases}

Twenty-two adults with ILD, diagnosed according the criteria established by the American Thoracic Society (ATS) and the European Respiratory Society (ERS) [16] [17], were included in this study.

\subsubsection{Control Group}

The control group included 15 adults without clinical evidence of ILD, Chronic Obstructive Pulmonary Disease (COPD), asthma Bronchoscopy was performed as follow up for post-intubation tracheal stenosis reparative surgery and BAL samples from middle lobe were collected. The characteristics for ILD patients and control subjects are shown in Table 1.

\subsection{Bronchoalveolar Lavage (BAL)}

Bronchoalveolar lavage was performed as previously described [18]. Sterile saline at room temperature was instilled through the bronchoscope in aliquots of $20 \mathrm{~mL}$ reaching a total volume of $140 \mathrm{~mL}$. It was harvested by gentle hand suction applied to each instilled syringe. The BAL was pooled in ice-cold tubes and centrifuged at $400 \mathrm{~g}$ for $10 \mathrm{~min}$ at $4^{\circ} \mathrm{C}$. Aliquots of the cell-free supernatant were stored at $-70^{\circ} \mathrm{C}$ until use. The cell pellet was 
Table 1. Characteristics of control subjects and ILD patients. NSIP: non-specific interstitial pneumonia. HP: hypersensitivity pneumonitis. FVC: forced vital capacity. TLC: total lung capacity. DLCO: diffusing capacity of the lung for carbon monoxide. AV: alveolar volume and ND: non determined. Data are presented as the median and quartiles (25\% and $75 \%$ ).

\begin{tabular}{|c|c|c|c|c|c|c|c|c|}
\hline \multirow{2}{*}{ Groups } & \multirow{2}{*}{$\mathrm{N}$} & \multirow{2}{*}{ Age (years) } & \multirow{2}{*}{ Sex } & \multicolumn{4}{|c|}{ Pulmonary Function Test } & \multirow{2}{*}{ Status Smoking } \\
\hline & & & & $\begin{array}{c}\text { FVC } \\
\text { (\% predicted) }\end{array}$ & $\begin{array}{c}\text { TLC } \\
\text { (\% predicted) }\end{array}$ & $\begin{array}{c}\text { DLCO } \\
\text { (\% predicted) }\end{array}$ & $\begin{array}{c}\mathrm{AV} \\
\text { (\% predicted) }\end{array}$ & \\
\hline CONTROL & 15 & $\begin{array}{c}31.0 \\
(24.0-58.0)\end{array}$ & $\begin{array}{c}\text { Female: } 7 \\
\text { Male: } 8\end{array}$ & $\begin{array}{c}90.0 \\
(94.0-102.0)\end{array}$ & ND & ND & ND & $\begin{array}{l}\text { Never: } 13 \\
\text { Previous: } 1 \\
\text { Current: } 1\end{array}$ \\
\hline NSIP & 4 & $\begin{array}{c}63.0 \\
(54.5-70.0)\end{array}$ & $\begin{array}{c}\text { Female: } 3 \\
\text { Male: } 1\end{array}$ & $\begin{array}{c}88.0 \\
(74.0-115.0)\end{array}$ & $\begin{array}{c}97.0 \\
(65.0-100.0)\end{array}$ & $\begin{array}{c}49.0 \\
(37.0-59.0)\end{array}$ & $\begin{array}{c}90.0 \\
(62.0-98.5)\end{array}$ & $\begin{array}{l}\text { Never: } 4 \\
\text { Previous: } 0 \\
\text { Current: } 0\end{array}$ \\
\hline SARCOIDOSIS & 6 & $\begin{array}{c}45.0 \\
(36.5-50.0)\end{array}$ & $\begin{array}{c}\text { Female: } 4 \\
\text { Male: } 2\end{array}$ & $\begin{array}{c}78.0 \\
(61.0-85.5)\end{array}$ & $\begin{array}{c}81.5 \\
(73.5-83.5)\end{array}$ & $\begin{array}{c}64.0 \\
(43.0-83.5)\end{array}$ & $\begin{array}{c}78.5 \\
(74.5-89.0)\end{array}$ & $\begin{array}{l}\text { Never: } 1 \\
\text { Previous: } 5 \\
\text { Current: } 0\end{array}$ \\
\hline HP & 12 & $\begin{array}{c}56.0 \\
(43.0-56.5)\end{array}$ & $\begin{array}{c}\text { Female: } 3 \\
\text { Male: } 9\end{array}$ & $\begin{array}{c}54.0 \\
(44.0-74.0)\end{array}$ & $\begin{array}{c}59.0 \\
(47.0-78.0)\end{array}$ & $\begin{array}{c}42.0 \\
(34.0-47.0)\end{array}$ & $\begin{array}{c}57.0 \\
(48.5-68.5)\end{array}$ & $\begin{array}{c}\text { Never: } 9 \\
\text { Previous: } 3 \\
\text { Current: } 0\end{array}$ \\
\hline
\end{tabular}

washed and BAL cells were resuspended in serum-free RPMI 1640 culture medium. Alveolar macrophages were purified by adherence to a 100 -mm diameter plastic tissue culture dishes at $37^{\circ} \mathrm{C}$ in a humidified atmosphere. After $45 \mathrm{~min}$ of incubation, the non-adherent cells were removed and the layer of adherent cells were washed twice with $10 \mathrm{ml}$ cold-sterile PBS. The purity of the macrophages was evaluated by measuring the expression of MHC class II cell surface receptor (HLA-DR) and CD64 (Fc-gamma receptor 1).

\subsection{Monocytes Purification}

Blood samples were obtained from ILD patients, mononuclear cells were isolated by standard density gradient centrifugation on Ficoll-Hypaque. Then, monocytes were purified by using magnetic microbeads conjugated with CD14 antibodies following the manufacture's recommendations. The purity was checked by flow cytometry $(>93 \%)$.

\subsection{Pulmonary Function Tests}

Pulmonary function tests (PFTs), including spirometry, plethismographic measurement of lung volumes and lung diffusing capacity for carbon monoxide (DLCO), were made according to ATS/ERS recommendations. A constant volume plethysmograph (Platinum Elite DL, Medical Graphics Corporation) was used for PFTs measurements. Predicted normal values were those of Crapo [19] [20].

\subsection{Enzyme Linked Immunosorbent Assay (ELISA)}

Hyaluronic acid levels in BAL and serum samples were measured with a competitive ELISA assay [21]. Briefly, 96-well microtiter plates were coated with $100 \mu \mathrm{g} / \mathrm{mL}$ HA. Samples or standard HA (Farmatrade, Argentina) were incubated in the presence of $1 \mu \mathrm{g} / \mathrm{mL}$ of biotinylated HA-binding protein (bHABP) (Calbiochem, La Jolla, $\mathrm{CA}$ ). The bHABP bound to the wells was determined using an avidin-biotin detection system (Vector labs, Burlingame, CA). The concentration of HA in the samples were calculated using a standard curve made with recombinant HA. Cytokines (IL- $1 \beta$, IL-6, IL-8, IFN- $\gamma$ and TNF- $\alpha$ ) in BAL and serum samples were determined by ELISA (R\&D Systems), following the manufacturer's recommendations.

\subsection{Flow Cytometry}

To analyse CD64 and HLA-DR expression, $5 \times 10^{6}$ alveolar macrophages were pre-incubated with heat-treated $\operatorname{IgG}(100 \mu \mathrm{g} / \mathrm{ml})$ to avoid non-specific binding of antibodies to the receptors for the $\mathrm{Fc}$ portion of $\operatorname{IgG}(\mathrm{Fc} \gamma \mathrm{R})$. Cells were then washed and incubated with a FITC-conjugated mAb directed to CD64 and PE-conjugated mAb directed to HLA-DR (BD PharMigen, San Diego, CA). Analysis was performed using a FACS flow cytometer 
and CellQuest software (BD Biosciences, San Jose, CA).

\subsection{Confocal Microscopy}

BAL cells were placed on poly-L-lysine-coated glass coverslips $(12 \mathrm{~mm})$. The coverslips were washed, and RPMI 1640 medium was added to further incubate the attached cells for 30 min. Cells were washed, fixed in 3\% paraformaldehyde, and washed twice with $0.1 \mathrm{mM}$ glycine. Cells were incubated with FITC-conjugated mAb directed to HLA-DR or CD64, washed and incubated with propidium iodide for nuclei staining. Coverslips were mounted on glass slides. Immunofluorescence images were acquired with a FluoView FV1000 confocal microscope (Olympus, Tokio, Japan) using a Plapon 60, 1.42 NA oil immersion objective and images were analyzed using the Olympus FV10-ASW software [22].

\subsection{Chemotaxis Assays}

BAL macrophages and monocytes isolated from ILD patients were used in chemotaxis assays. Migration was measured using a 24-transwell plate (8 $\mu$ m pore size, BD FalconTM, USA) [23]. Briefly, cells $\left(3 \times 10^{5}\right.$ cells $\left./ \mathrm{ml}\right)$ were added to the upper compartment. Serum-free RPMI medium (diluent), HA (0.25 - $0.45 \times 10^{6}$ Da Contipro Group-Farmatrade, Argentine) or BAL from ILD patients, pre-treated, or not, with hyaluronidase for 30 min at $37^{\circ} \mathrm{C}$ (5 U/mL, from bovine testes, Sigma-Aldrich, USA), was added to the lower compartment. After 90 min of incubation in $5 \% \mathrm{CO}_{2}$ at $37^{\circ} \mathrm{C}$, filters were removed. Cells on the upper side of the membrane were scraped; cells attached to the lower side of the membrane were fixed in $2 \%$ formaldehyde, stained with $10 \%$ DAPI and counted in a fluorescence microscope (OLYMPUS BX51, Olympus Corporation). In addition, migrating cells from the lower compartment were collected and counted by flow cytometry as the number of cells acquired in a minute under a defined flow rate. The migration index was calculated by determining the ratio of migrated cells towards HA or BAL versus control medium, taking the spontaneous migration in control wells as $100 \%$. To evaluate the capacity of anti-human CD44 monoclonal antibodies (clonKM81) to inhibit HA-mediated migration, alveolar macrophages were incubated with the mAbKM81 $(20 \mu \mathrm{g} / \mathrm{ml})$ at $4^{\circ} \mathrm{C}$ for $30 \mathrm{~min}$ before the start of the migration assay. Isotype controls were also included in the experiments. To evaluate random migration, chemokinesis controls were performed by adding HA to both, the upper and lower compartment of the chamber.

\subsection{Statistical Analysis}

Differences between the groups were evaluated by the non-parametric Kruskall Wallis and Dunn's Multiple comparison tests or by one way analysis of variance (ANOVA) and Bonferroni's multiple comparison test. To evaluate the degree of association between HA, cytokine levels and lung function parameters we used a linear regression test. Analysis was performed using Prism 4 software (Graph Pad, La Jolla, CA) and Statistixs (USA).

\section{Results}

\subsection{Increase in Concentrations of Hyaluronic Acid in Bronchoalveolar Lavage from Interstitial Lung Disease Patients Respect to Healthy Subjects}

We found a significant increase in the concentrations of HA in BAL from ILD patients compared with controls: non-specific interstitial pneumonia: NSIP: $2057.0 \pm 419.9 \mathrm{ng} / \mathrm{mL}(\mathrm{p}<0.01)$; hypersensitivity pneumonitis: HP: $1975.0 \pm 199.3 \mathrm{ng} / \mathrm{mL}(\mathrm{p}<0.001)$ and sarcoidosis: $1839.0 \pm 147.9 \mathrm{ng} / \mathrm{mL}(\mathrm{p}<0.01)$ vs controls: $623.5 \pm 48.1$ ng/mL (Figure 1(a)). We also measured serum concentrations of HA and found no differences between ILD patients and controls: NSIP: $230.0 \pm 22.0 \mathrm{ng} / \mathrm{mL}, \mathrm{HP}: 242.0 \pm 50.5 \mathrm{ng} / \mathrm{mL}$, sarcoidosis: $270.2 \pm 49.0 \mathrm{ng} / \mathrm{mL}$ vs controls: $210.8 \pm 22.1 \mathrm{ng} / \mathrm{mL}$.

\subsection{Increase of Cell Count in Bronchoalveolar Lavage from Interstitial Lung Disease Patients Respect to Healthy Subjects}

As shown in Figure 1(b), BAL from ILD patients contained higher number of cells compared with controls: NSIP: $(0.50 \pm 0.07) \times 10^{6} \mathrm{cell} / \mathrm{mL}(\mathrm{p}<0.05)$; HP: $(0.73 \pm 0.13) \times 10^{6} \mathrm{cells} / \mathrm{mL}(\mathrm{p}<0.01)$ and sarcoidosis: $(0.82$ $\pm 0.28) \times 10^{6} \mathrm{cell} / \mathrm{mL}(\mathrm{p}<0.05)$ vs controls $=(0.19 \pm 0.03) \times 10^{6} \mathrm{cell} / \mathrm{mL}(\mathrm{n}=15)$. 


\subsection{Concentrations of Cytokines from Interstitial Lung Disease Patients Compared with Control Subjects}

We measured the inflammatory cytokines IL- $1 \beta$, IL-6, IL-8, IFN- $\gamma$ and TNF- $\alpha$ in BAL samples. There were no differences between IFN- $\gamma$, TNF- $\alpha$, IL- $1 \beta$ and IL- 8 concentrations in BAL from ILD patients compared with control subjects (Figures 2(a)-(d)). ILD patients showed higher levels of IL-6 in BAL, compared with controls: NSIP: $359.2 \pm 88.4$ pg/mL (p < 0.001), HP: $150.4 \pm 36.97$ pg/mL (p < 0.05), sarcoidosis: $248.5 \pm 71.4$ pg/mL (p $<0.01$ ), respect to controls: $13.47 \pm 2.6 \mathrm{pg} / \mathrm{mL}$ (Figure 2(e)), however in serum we didn’t find significant dif-
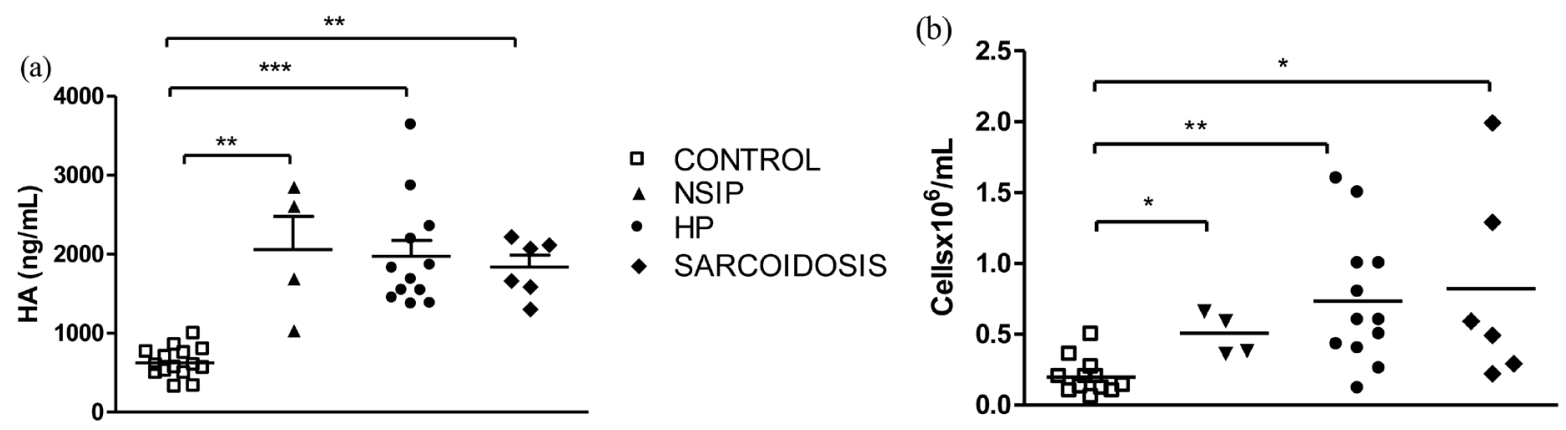

Figure 1. Increased levels of HA and cell counts in BAL from ILD patients compared with control subjects. HA levels (a) and cell counts (b) were quantified in BAL from NSIP $(n=4)$, HP $(n=12)$, Sarcoidosis $(n=6)$ patients, and control subjects $(n=15) .{ }^{*} p<0.05,{ }^{* *} p<0.01$, and ${ }^{* * *} p<0.001$ vs control subjects.

(a)

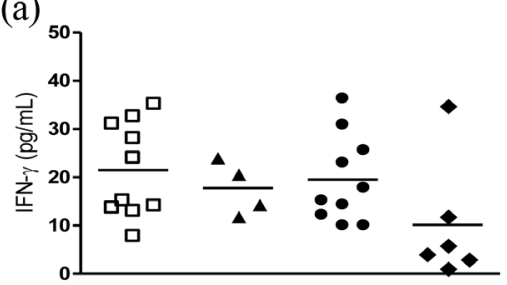

(c)

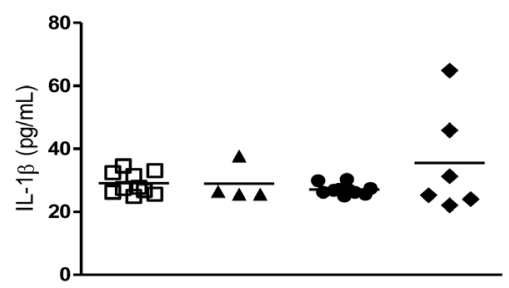

(e)

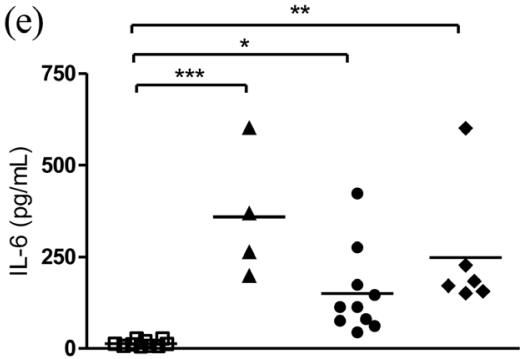

(b)

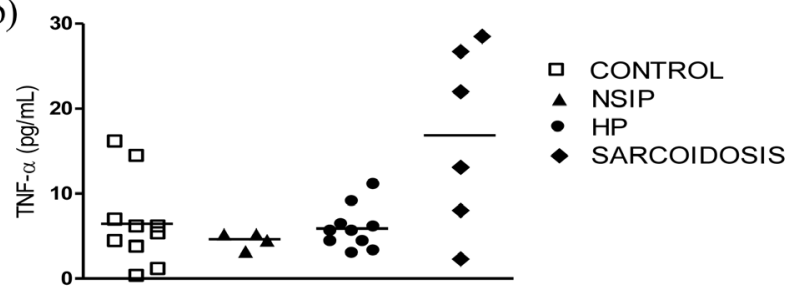

(d)

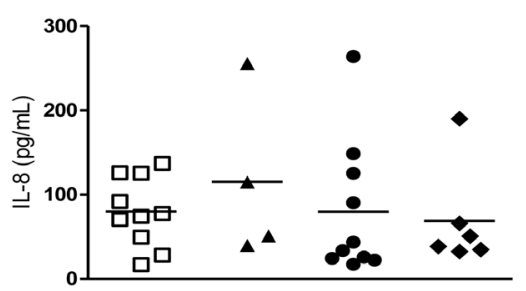

(f)

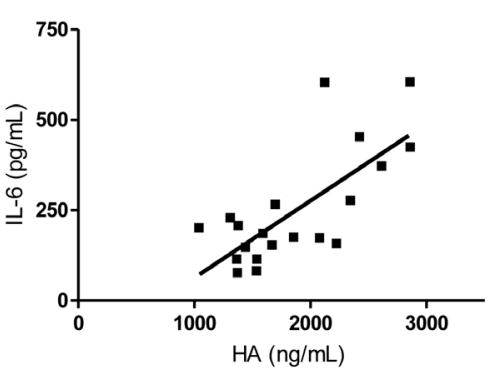

Figure 2. Concentrations of cytokines in BAL samples from ILD patients. The levels of IFN- $\gamma$ (a), TNF- $\alpha$ (b), IL1- $\beta$ (c), IL-8 (d), and IL-6 (e) were analyzed by ELISA. (f) Linear regression between the concentrations of IL-6 and HA in BAL samples from ILD patients. Spearman $r=0.53$ and $p<0.001$. ${ }^{*} p<0.05,{ }^{* *} p<$ 0.01 and ${ }^{* * *} \mathrm{p}<0.001$. 
ferences (data not shown). Interestingly, a positive correlation was found in the BAL of ILD patients between the levels of HA and IL-6 (Figure 2(f)) (Spearman $r=0.53$ and $p<0.001$ ).

\subsection{Relationship between Hyaluronic Acid Levels in Bronchoalveolar Lavage and Pulmonary Function Tests}

We next analyzed the relationship between the concentrations of HA in BAL and the different pulmonary function tests performed in ILD patients (see Table 1). These studies revealed an inverse correlation between BAL HA levels and the DLCO/VA ratio (Spearman r: -0.59 , $\mathrm{p}<0.01$; Figure 3). However, we didn’t find similar relationship between the rest of parameters evaluated (TLC or FVC) and HA concentrations.

\subsection{Hyaluronic Acid Induces the Chemotaxis of Alveolar Macrophages and Peripheral Monocytes}

In a first set of experiments, we characterized BAL adherent cells recovered from ILD patients by using mAb directed to HLA-DR and CD64. Figure 4 shows that, as expected, adherent cells were mostly positive for the expression of HLA-DR and CD64, evaluated by both flow cytometry (Figure 4(a)) and confocal microscopy (Figure 4(b)). Migration assays were performed by using HA as chemoattractant. Results in Figure 5(a) indicated that HA stimulated macrophage migration in doses depend manner. Moreover, Figure 5(b) shows that pre-treatment of macrophages with antibodies directed to CD44 completely prevented the ability of HA to stimulate macrophage migration while isotype controls did not exert any effect. Moreover, the simultaneous addition of HA to both the upper and the lower wells of the transwell plate did not stimulate the migration of macrophages, suggesting that HA stimulates the chemotaxis, but not the chemokinesis of macrophages. We also observed that a pool of BAL from ILD patients, containing a concentration of HA of $2645 \mathrm{ng} / \mathrm{ml}$ stimulated the migration of macrophages. Of note, this response was completely prevented by the pre-treatment of BAL with hyaluronidase (Figure 5(d)), thus suggesting a major role for HA in the chemotactic response induced by BAL. Moreover, we showed similar results when we performed the migration assay using monocytes purified from peripheral blood (Figure 5(c) and Figure 5(e)).

\section{Discussion}

In this work we analyzed the role of HA in the migration of inflammatory cells. Our results suggest that AH could contribute to the recruitment of macrophages and monocytes through a CD44-dependent process leading to exacerbation of lung inflammation in ILD patients. As it has been previously demonstrated, the tissue microenvironment plays a critical role in regulation of inflammation and ECM degradation products might contribute actively in the inflammatory process [24]. Endogenous ligands of TLR are released at the site of tissue injury, and can activate the innate immune system prompting "danger signals" [25] [26]; however the mechanisms underlying the pathogenesis of ILD are poorly understood. In the present study we analyzed whether HA might be

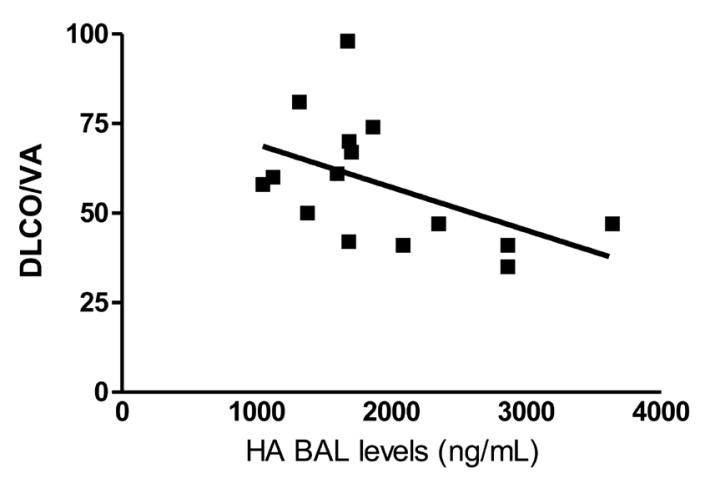

Figure 3. Relationship between pulmonary function tests and levels of HA in BAL from ILD patients. Linear regression between DLCO/VA ratio vs levels of HA in BAL samples; Spearman $\mathrm{r}=-0.59, \mathrm{p}<0.01$. 
(a)
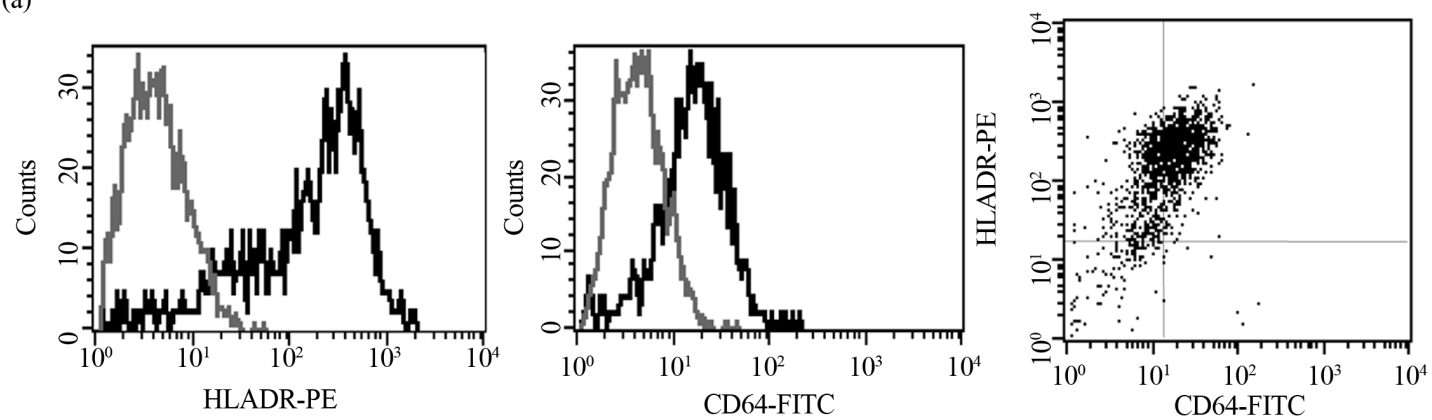

(b)

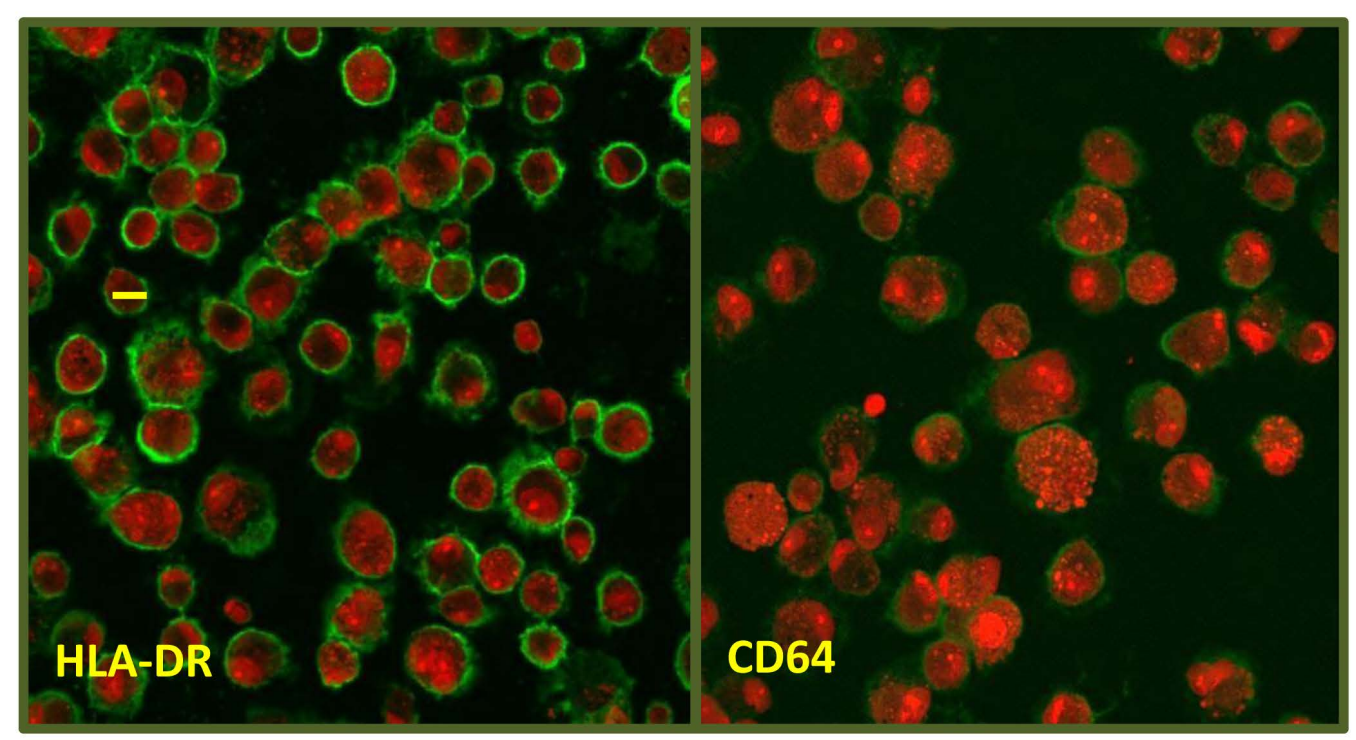

Figure 4. Characterization of adherent cells purified from ILD patients. The expression of HLA-DR and CD64 was analyzed by flow cytometry (a) and confocal microscopy (b). In (a), histograms and a dot-plot from a representative experiment is shown. In (b), cells were labeled with antibodies directed to HLA-DR (green) or CD64 (green), and nuclei staining was performed with propidium iodide (red). Bar: $10 \mu \mathrm{m}$. Graphs are representative of five independent experiment.

involved.

We found that patients with ILD showed a significant increase in HA and IL-6 levels in BAL compared with control subjects. In accordance with our results, other reports have previously shown increased levels of HA in patients with farmer's lung-HP [27] [28], sarcoidosis [10], asbestos-exposed individuals [29] and patients with idiopathic pulmonary fibrosis [30]. Our results raise the question about a possible role for HA in the pathogenesis of ILD. In fact, we observed a positive correlation between HA and local inflammation determined by IL-6 level and an inverse correlation between levels of HA in BAL samples from ILD patients and DLCO/VA ratio.

Accumulation of HA has shown to be associated to progressive tissue fibrosis [9] and its most important cell surface receptor CD44, was shown to be involved in the HA-induced leukocyte infiltration in a murine model of arthritis [31]. Moreover, in a recent report, Li and coworkers [32] have reported that severe lung fibrosis requires an invasive fibroblast phenotype regulated by HA and CD44. Thus, these observations suggest that HA might contribute to the pathogenesis of ILD by stimulating both the local recruitment of inflammatory cells and the profibrotic activity of fibroblasts. In line with these results, we found that HA, participates in the recruitment of monocytes in a CD44-dependent manner in patients with ILDs.

Though we analyzed a small number of patients we think that HA could play an important role in the recruitment of monocytes towards the alveolar space, leading to exacerbation of lung inflammation in patients with ILD. These findings suggest a novel potential approach to the treatment and/or prevention of ILD. 
(a)

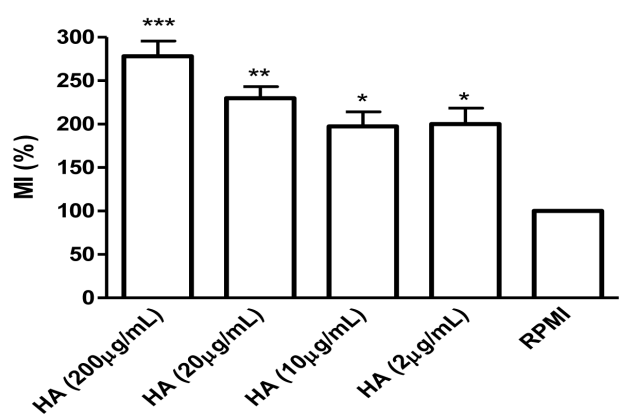

(b)

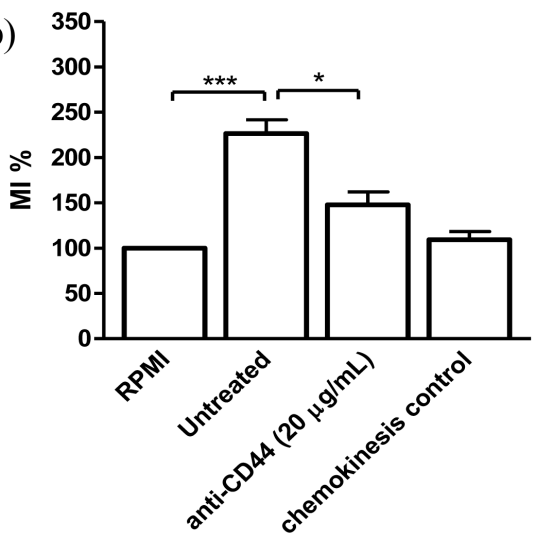

(d)

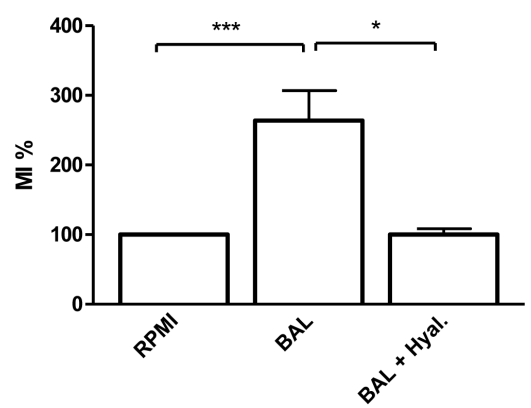

(c) Alveolar Macrophages

(c)

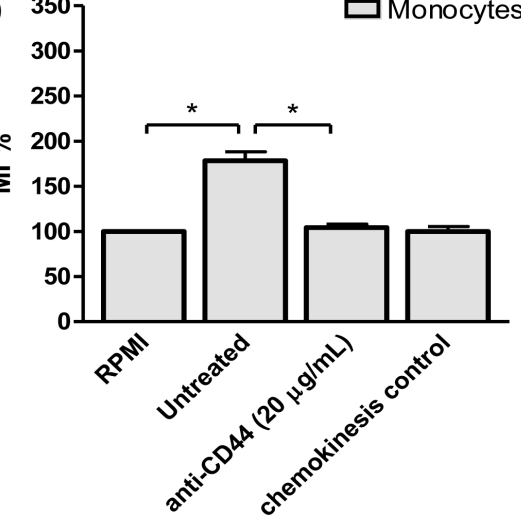

(e)

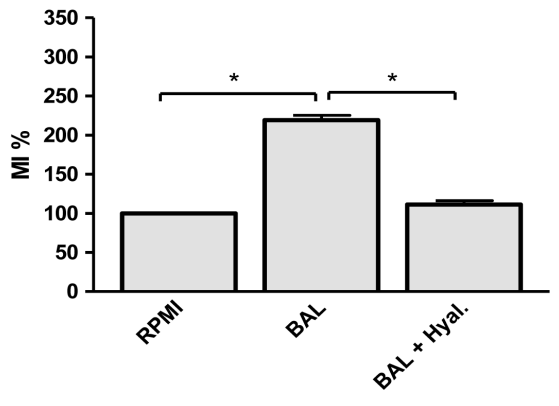

Figure 5. Chemotaxis of BAL macrophages or monocytes purified from peripheral blood induced by HA. In all cases, BAL macrophages were isolated from ILD patients. a) Migration of alveolar macrophages in response to different concentrations of HA. Results are the mean \pm SEM $(n=10)$. (b) Macrophages (c) or monocytes were pre-treated with the anti-CD44 IgGmAb KM81 $(20 \mu \mathrm{g} / \mathrm{ml})$ for $30 \mathrm{~min}$ at $4^{\circ} \mathrm{C}$ before the addition of HA $(2.5 \mu \mathrm{g} / \mathrm{ml})$. The chemokinesis control was performed by adding HA $(20 \mu \mathrm{g} / \mathrm{ml})$ to both, the upper and the lower compartment of the chamber. Migration towards BAL using macrophages (d) or monocytes (e) were performed. A pool of BAL harvested from ILD patients containing a concentration of HA of $2245 \mathrm{ng} / \mathrm{ml}$, were pre-treated, or not, with hyaluronidase $(5 \mathrm{U} / \mathrm{ml})$ for $30 \mathrm{~min}$ at $37^{\circ} \mathrm{C}$. In all cases, the results are expressed as the migration index: MI $(\%)=($ Number of cells that migrated towards HA or BAL/Number of cells that migrated towards RPMI $) \times 100(\mathrm{n}=5-10) .{ }^{*} \mathrm{p}<0.05,{ }^{* *} \mathrm{p}<0.01$ and ${ }^{* * *} \mathrm{p}<0.001$.

\section{Conflict of Interest Statement}

Authors declare that no conflict of interest exists in the development of this work. This work was supported by grants from University of Buenos Aires (UBACYT-B021) and CONICET (PIP-0199).

\section{Acknowledgements}

We are especially grateful to Dr David D. Gutterman (Medical College of Wisconsin, Milwaukee); Dr. Henri 
Colt (University of California, Irvine) and Eric Edell (Mayo Clinic) by reading and correcting the manuscript with such dedication. We also thank Dr. Pauline Johnson (University of British Columbia, Vancouver, Canada) for providing the blocking anti-CD44 Mab (KM81).

\section{References}

[1] King Jr., T.E. (2005) Clinical Advances in the Diagnosis and Therapy of the Interstitial Lung Diseases. American Journal of Respiratory and Critical Care Medicine, 172, 268-279. http://dx.doi.org/10.1164/rccm.200503-483OE

[2] Kim, R. and Meyer, K.C. (2008) Therapies for Interstitial Lung Disease: Past, Present and Future. Therapeutic Advances in Respiratory Disease, 2, 319-338. http://dx.doi.org/10.1177/1753465808096948

[3] Nathan, S.D., Shlobin, O.A., Weir, N., Ahmad, S., Kaldjob, J.M., Battle, E., Sheridan, M.J. and du Bois, R.M. (2011) Long-Term Course and Prognosis of Idiopathic Pulmonary Fibrosis in the New Millennium. Chest, 141, 221-229. http://dx.doi.org/10.1378/chest.10-2572

[4] Selman, M., King, T.E., Pardo, A., American Thoracic Society, European Respiratory Society and American College of Chest Physicians (2001) Idiopathic Pulmonary Fibrosis: Prevailing and Evolving Hypotheses about Its Pathogenesis and Implications for Therapy. Annals of Internal Medicine, 134, 136-151. http://dx.doi.org/10.7326/0003-4819-134-2-200101160-00015

[5] Strieter, R.M. (2005) Pathogenesis and Natural History of Usual Interstitial Pneumonia: The Whole Story or the Last Chapter of a Long Novel. Chest, 128, 526S-532S. http://dx.doi.org/10.1378/chest.128.5_suppl_1.526S

[6] Vasakova, M., Sterclova, M., Kolesar, L., Slavcev, A., Pohunek, P., Sulc, J., Skibova, J. and Striz, I. (2009) Bronchoalveolar Lavage Fluid Cellular Characteristics, Functional Parameters and Cytokine and Chemokine Levels in Interstitial Lung Diseases. Scandinavian Journal of Immunology, 69, 268-274.

http://dx.doi.org/10.1111/j.1365-3083.2008.02222.x

[7] Jiang, D., Liang, J. and Noble, P.W. (2011) Hyaluronan as an Immune Regulator in Human Diseases. Physiological Reviews, 91, 221-264. http://dx.doi.org/10.1152/physrev.00052.2009

[8] Hällgren, R., Samuelsson, T., Laurent, T.C. and Modig, J. (1989) Accumulation of Hyaluronan (Hyaluronic Acid) in the Lung in Adult Respiratory Distress Syndrome. The American Review of Respiratory Disease, 139, 682-687. http://dx.doi.org/10.1164/ajrccm/139.3.682

[9] Bjermer, L., Lundgren, R. and Hällgren, R. (1989) Hyaluronan and Type III Procollagen Peptide Concentrations in Bronchoalveolar Lavage Fluid in Idiopathic Pulmonary Fibrosis. Thorax, 44, 126-131. http://dx.doi.org/10.1136/thx.44.2.126

[10] Bjermer, L., Eklund, A. and Blaschke, E. (1991) Bronchoalveolar Lavage Fibronectin in Patients with Sarcoidosis: Correlation to Hyaluronan and Disease Activity. European Respiratory Journal, 4, 965-971.

[11] Noble, P.W. and Jiang, D. (2006) Matrix Regulation of Lung Injury, Inflammation, and Repair: The Role of Innate Immunity. Proceedings of the American Thoracic Society, 3, 401-404. http://dx.doi.org/10.1513/pats.200604-097AW

[12] Taylor, K.R., Trowbridge, J.M., Rudisill, J.A., Termeer, C.C., Simon, J.C. and Gallo R.L. (2004) Hyaluronan Fragments Stimulate Endothelial Recognition of Injury through TLR4. The Journal of Biological Chemistry, 279, 1707917084. http://dx.doi.org/10.1074/jbc.M310859200

[13] Lesley, J. and Hyman Rand Kincade, P.W. (1993) CD44 and Its Interaction with Extracellular Matrix. Advanced Immunology, 54, 271-335. http://dx.doi.org/10.1016/S0065-2776(08)60537-4

[14] Jiang, D., Liang, J., Fan, J., Yu, S., Chen, S., Luo, Y., Prestwich, G.D., et al. (2005) Regulation of Lung Injury and Repair by Toll-Like Receptors and Hyaluronan. Nature Medicine, 11, 1173-1179. http://dx.doi.org/10.1038/nm1315

[15] Kuipers, M.T., van der Poll, T., Schultz, M.J. and Wieland, C.W. (2011) Bench-to-Bedside Review: Damage-Associated Molecular Patterns in the Onset of Ventilator-Induced Lung Injury. Critical Care, 15, 235-246. http://dx.doi.org/10.1186/cc10437

[16] American Thoracic Society, European Respiratory Society (2002) American Thoracic Society/European Respiratory Society International Multidisciplinary Consensus Classification of the Idiopathic Interstitial Pneumonias. American Journal of Respiratory and Critical Care Medicine, 165, 277-304. http://dx.doi.org/10.1164/ajrccm.165.2.ats01

[17] Travis, W.D., Costabel, U., Hansell, D.M., King Jr., T.E., Lynch, D.A. and Nicholson, A.G. (2013) An Official American Thoracic Society/European Respiratory Society Statement: Update of the International Multidisciplinary Classification of the Idiopathic Interstitial Pneumonias. American Journal of Respiratory and Critical Care Medicine, 188, 733-748. http://dx.doi.org/10.1164/rccm.201308-1483ST

[18] Meyer, K.C., Raghu, G., Baughman, R.P., Brown, K.K., Costabel, U., du Bois, R.M., et al. (2012) An Official American Thoracic Society Clinical Practice Guideline: The Clinical Utility of Bronchoalveolar Lavage Cellular Analysis in Interstitial Lung Disease. American Journal of Respiratory and Critical Care Medicine, 185, 1004-1014. 
http://dx.doi.org/10.1164/rccm.201202-0320ST

[19] Miller, M.R., Hankinson, J., Brusasco, V., Burgos, F., Casaburi, R., Coates, A. and Crapo, R. (2005) Standardisation of Spirometry. European Respiratory Journal, 26,319-338. http://dx.doi.org/10.1183/09031936.05.00034805

[20] Macintyre, N., Crapo, R.O., Viegi, G., Johnson, D.C., van der Grinten, C.P., Brusasco, V. and Burgos, F. (2005) Standardisation of the Single-Breath Determination of Carbon Monoxide Uptake in the Lung. European Respiratory Journal, 26, 720-735. http://dx.doi.org/10.1183/09031936.05.00034905

[21] Cordo Russo, R.I., Ernst, G., Lompardía, S., Blanco, G., Álvarez, É., Garcia, M.G. and Hajos, S. (2012) Increased Hyaluronan Levels and Decreased Dendritic Cell Activation Are Associated with Tumor Invasion in Murine Lymphoma Cell Lines. Immunobiology, 217, 842-850. http://dx.doi.org/10.1016/j.imbio.2011.12.006

[22] Jancic, C.C., Cabrini, M., Gabelloni, M.L., Rodríguez, Rodrigues, C., Salamone, G., Trevani, A.S. and Geffner, J. (2012) Low Extracellular pH Stimulates the Production of IL-1 $\beta$ by Human Monocytes. Cytokine, 57, 258-268. http://dx.doi.org/10.1016/j.cyto.2011.11.013

[23] Ernst, G., Lompardía, S., Cordo Russo, R., Gentilini, V., Venturiello, S., Galíndez, F., Grynblat, P. and Hajos, S.E. (2012) Corticosteroid Administration Reduces the Concentration of Hyaluronan in Bronchoalveolar Lavage in a Murine Model of Eosinophilic Airway Inflammation. Inflammation Research, 61, 1309-1317. http://dx.doi.org/10.1007/s00011-012-0530-y

[24] Collins, S.L., Black, K.E., Yee, C.-L., Ahn, Y.-H., Cole, P.A., Powell, J.D. and Horton, M.R. (2011) Hyaluronan Fragments Promote Inflammation by Down-Regulating the Anti-Inflammatory A2a Receptor. American Journal of Respiratory Cell and Molecular Biology, 45, 675-683. http://dx.doi.org/10.1165/rcmb.2010-0387OC

[25] Scheibner, K.A., Lutz, M.A., Boodoo, S., Fenton, M.J., Powell, J.D. and Horton, M.R. (2006) Hyaluronan Fragments Act as an Endogenous Danger Signal by Engaging TLR2. The Journal of Immunology, 177, 1272-1281.

[26] Powell, J.D. and Horton, M.R. (2005) Threat Matrix: Low-Molecular-Weight Hyaluronan (HA) as a Danger Signal. Immunologic Research, 31, 207-218. http://dx.doi.org/10.1385/IR:31:3:207

[27] Bjermer, L., Engström-Laurent, A., Lundgren, R., Rosenhall, L. and Hällgren, R. (1987) Hyaluronate and Type III Procollagen Peptide Concentrations in Bronchoalveolar Lavage Fluid as Markers of Disease Activity in Farmer's Lung. British Medical Journal (Clinical Research Ed.), 295, 803-806. http://dx.doi.org/10.1136/bmj.295.6602.803

[28] Cormier, Y,. Laviolette, M., Cantin, A., Tremblay, G.M. and Bégin, R. (1993) Fibrogenic Activities in Bronchoalveolar Lavage Fluid of Farmer's Lung. Chest, 104, 1038-1042. http://dx.doi.org/10.1378/chest.104.4.1038

[29] Cantin, A.M., Larivée, P., Martel, M. and Bégin, R. (1992) Hyaluronan (Hyaluronic Acid) in Lung Lavage of Asbestos-Exposed Humans and Sheep. Lung, 170, 211-220. http://dx.doi.org/10.1007/BF00174118

[30] Milman, N., Kristensen, M.S. and Bentsen, K. (1995) Hyaluronan and Procollagen Type III Aminoterminal Peptide in Serum and Bronchoalveolar Lavage Fluid from Patients with Pulmonary Fibrosis. APMIS, 103, 749-754. http://dx.doi.org/10.1111/j.1699-0463.1995.tb01433.x

[31] Mikecz, K., Brennan, F.R., Kim, J.H. and Glant, T.T. (1995) Anti-CD44 Treatment Abrogates Tissue Oedema and Leukocyte Infiltration in Murine Arthritis. Nature Medicine, 1, 558-563. http://dx.doi.org/10.1038/nm0695-558

[32] Li, Y., Jiang, D., Liang, J., Meltzer, E.B., Gray, A., Miura, R., Wogensen, L., Yamaguchi, Y. and Noble, P.W. (2011) Severe Lung Fibrosis Requires an Invasive Fibroblast Phenotype Regulated by Hyaluronan and CD44. The Journal of Experimental Medicine, 208, 1459-1471. http://dx.doi.org/10.1084/jem.20102510 